PARQUE E APA

\section{Caatinga tem novas unidades de conservação}

A criação de duas novas unidades de conservação na Caatinga em abril deste ano, o Parque Nacional do Boqueirão da Onça e a Área de Proteção Ambiental (APA) do Boqueirão da Onça, ambas na Bahia, atendeu a uma reivindicação antiga de ambientalistas e cientistas e reacendeu o debate sobre a implementação de estratégias de conservação para o único bioma exclusivamente brasileiro.

As unidades de conservação criadas na região conhecida como Boqueirão da Onça agregaram ao Sistema Nacional de Unidades de Conservação da Natureza (SNUC) aproximadamente 853,2 mil hectares, ou o equivalente a 853,2 mil campos de futebol do Estádio do Maracanã. A região é importante porque verte água para recarregar o rio São Francisco que historicamente sofre pela ação antrópica e diminuição da vazão pelo uso da irrigação ao longo das margens. "O Boqueirão tem a maior área preservada contínua de Caatinga e as novas unidades de conservação incluem parte desse território", destacou o biólogo e analista ambiental do Centro Nacional de Conservação de Mamíferos Carnívoros (Cenap), do Instituto Chico Mendes de Conservação da Biodiversidade (ICMBio), Rogério Cunha de Paula.

As unidades de conservação no Boqueirão da Onça estão localizadas em uma região de baixa densidade demográfica e baixo Índice de Desenvolvimento Humano (IDH) nos mu-

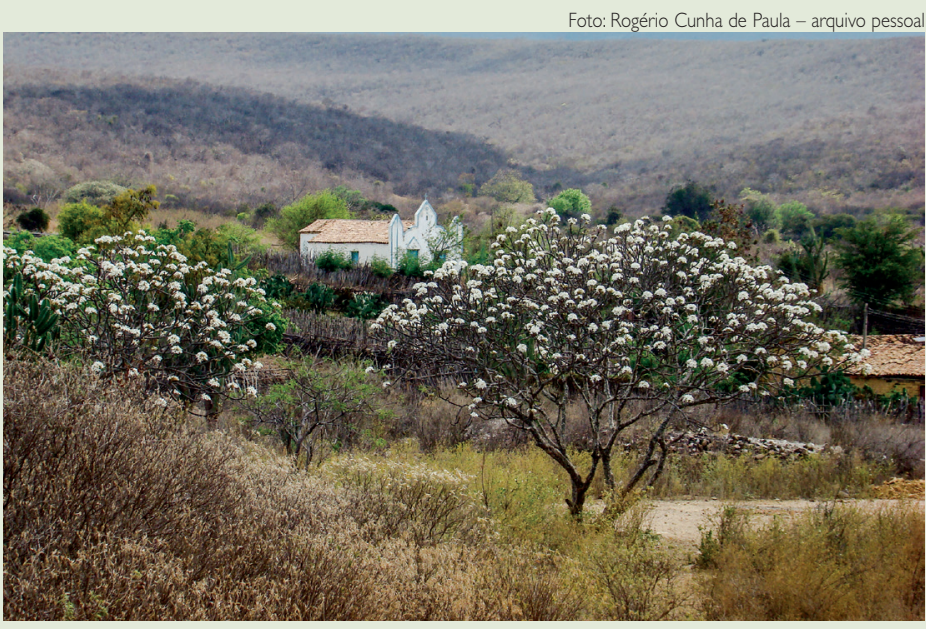

Boqueirão da

Onça (BA): a criação das UCs vai facilitar a realização de estudos e coleta de dados

nicípios baianos de Sento Sé, Campo Formoso, Sobradinho, Juazeiro e Umburanas. As UCs do Boqueirão da Onça elevaram de 7,8\% para 8,8\% o percentual de unidades de conservação na Caatinga. Ainda assim, o bioma continua como um dos menos protegidos do país. Menos de $2 \%$ da Caatinga é área de proteção integral da biodiversidade, a categoria de proteção menos flexível.

BIODIVERSIDADE Importantes nascentes brotam nas serras do Boqueirão da Onça, atraindo a vida animal e vegetal. Parte das nascentes estão dentro dos limites do novo parque nacional. A regiāo tem desfiladeiros, cavernas, inscriçōes rupestres milenares, populaçōes tradicionais e, claro, uma imensa diversidade biológica. O Boqueirão da Onça concentra espécies da flora e fauna nativas ameaçadas de extinção ou vulneráveis. De acordo com o pesquisador da Universidade do Vale do São Francisco (Univasf), José Alves de Siqueira Filho, existem na região mais de 900 espécies de plantas de 120 famílias botânicas. Animais como a onça-pintada e a ararinha-azul-de-lear têm na região um dos principais refúgios em área natural na Caatinga. A bióloga e coordenadora do programa Amigos da Onça, Cláudia Bueno de Campos, estima que circulem na região em torno de 30 onças-pintadas. "A Caatinga ainda é pouco explorada cientificamente, sobretudo em relação à flora. Além disso, ainda sabemos pouco sobre ecologia das espécies e a sua vulnerabilidade. A criação do parque, uma unidade de proteção integral, éimportante no sentido de ser um apoio na realização de estudos e a coleta de dados", destacou. Um incêndio que atingiu o Parque Nacional do Boqueirão da Onça entre o final de agosto e a primeira quinzena de setembro de 2018 reforçou a importância da criação dessa unidade de conservação. O fogo consumiu 3.075 hectares de caatinga nativa, segundo informou a Divisão de Monitoramento e Informaçōes Ambientais (DMIF) do ICMBio. "O incêndio aconteceu em um período em que a região está muito seca. $\mathrm{O}$ combate só foi possível porque a existência do parque levou o poder público a mobilizar brigadistas", destacou Campos.

Mauricio Boff 